\title{
7. DATA REPORT: HEAVY MINERAL ANALYSIS OF THE UPPER MIOCENE(?) TO PLEISTOCENE SANDS, CAPE MAY SITE ${ }^{1}$
}

\author{
Frederick L. Muller ${ }^{2}$ and Jane Uptegrove ${ }^{2}$
}

\section{INTRODUCTION}

The objective of this study is to do a survey of the heavy minerals (minerals with a specific gravity greater than that of quartz, S.G. > 2.65) at selected intervals of the upper $300 \mathrm{ft}$ of the Ocean Drilling Program Leg 150X Cape May corehole. The heavy mineral suites and the weight percentage of the composition are described. Some of the environments of deposition have been described by Miller et al. (Chapter 14, this volume) and Miller, et al. (1996) for much of the core using sedimentological and paleontological data. Identification of the heavy mineral suites will increase the existing body of knowledge of the relationship of heavy minerals to environments of deposition. The age of the section between 140 and $353 \mathrm{ft}$ (42.7 and 107.6 $\mathrm{m}$ ) is uncertain. Owens et al. (1995) map this unit as Pliocene while deVerteuil (Chapter 11, this volume) notes it is upper Miocene.

\section{METHODS}

Samples were taken at intervals from the upper $300 \mathrm{ft}(91.4 \mathrm{~m})$ (Fig. 1). The lithology was generally fine to very fine sand (Table 1; Fig. 1). The sample was dried, weighed, and then cleaned in a solution of sodium carbonate and distilled water that was heated to a temperature just below the boiling point. The samples were washed on a $63-\mu \mathrm{m}$ screen ( $230 \mathrm{mesh}$ ) because the economically important heavy minerals are found in the sand and very fine sand fraction in coastal plain sediments (Grosz et al., 1989, 1990; Uptegrove et al., 1991). The residue was dried, weighed, and then sieved on a 2-mm screen to separate the sand and gravel fractions (Table 1; Fig. 1). Each sample was then floated in sodium polytungstate liquid. Most heavy minerals have a specific gravity greater than 2.89 , that of polytungstate, which was used instead of the toxic bromoform (S.G. $=2.65$ ).

The residue heavy mineral concentrate was dried and the float archived. The concentrate was processed through a Frantz Magnetic Barrier Separator with a side-slope angle of $20^{\circ}$ and a forward-slope angle of $30^{\circ}$ at different amperages to produce six fractions. The 203 fraction, which approximates the hand magnetic fraction and freefall fractions of other workers (Grosz et al. 1989, 1990) was separated at 0.1 ampere (A) current. (Fraction numbers 203-208 are a labeling convention of the separation method of Grosz et al. (1990) used in this study.) The separate is magnetic and is typically made up of magnetite, ilmenite, and paramagnetic phases with inclusions. The 204 fraction is the residue of the 0.2 A run, and is generally composed of 70\%-90\% stoichiometric ilmenite (Uptegrove et al., 1991). The 205 fraction is produced by a run at $0.4 \mathrm{~A}$ current and is generally characterized by an assemblage of dark red and pink garnets, ilmenite (enriched in titanium), epidote, and pyrobole (pyroxene and amphibole). The next run at 0.6 A produces the 206 fraction. The dominant mineral phases are pyroboles, leucoxene (a variable mix-

${ }^{1}$ Miller, K.G., and Snyder, S.W. (Eds.), 1997. Proc. ODP, Sci. Results, 150X: College Station, TX (Ocean Drilling Program).

${ }^{2}$ Department of Environmental Protection, New Jersey Geological Survey, CN 427, Trenton, NJ 08625, U.S.A. janeu@njgs.dep.state.nj.us ture of pseudo-rutile and other titanium alteration by-products), epidote, staurolite, and minor amounts of tourmaline. The amount of garnet present in this fraction is significantly less than in the 205 fraction. Monazite may be present in visual percents ranging from trace $(<1 \%)$ to $3 \%$. The altered ilmenite is depleted in iron and enriched in titanium. The 207 and 208 fractions are separated using a current of $1.8 \mathrm{~A}$. This divides the paramagnetic phases and nonmagnetic phases. The paramagnetic 207 fraction is dominated by tourmaline and leucoxene. Pyroboles, staurolite, epidote, and garnet are reduced to amounts estimated visually at $<5 \%$. Rutile, brookite, and anatase, the titanium minerals apparent here, are referred to collectively as "rutile." The altered ilmenite is an important minor constituent as well. The aluminosilicate minerals andalusite, kyanite, and sillimanite (collectively counted and reported as "aluminosilicates") are conspicuous in this fraction, as is zircon. The 208 fraction is dominated by the aluminosilicate phases and zircon, whereas minor amounts of rutile, leucoxene, and altered ilmenite are present. Quartz also is concentrated in this fraction.

The identification of the mineral suites of the fractions 203-208 was made using a binocular microscope with an illuminated stage with a dark, opaque background option. The dark option is very useful because it illuminates the interior of the grain and allows the observer to discriminate a truly opaque black or dark grain from a translucent one. This is important in discriminating grains of ilmenite (opaque) from dense, dark green, brown, or black minerals like tourmaline, pyroxene, or amphibole. The methods of mineral grain identification are described in Grosz et al. (1989, 1990), Uptegrove et al. (1991), and Mange and Maurer (1992). Also, the use of a powerful ultraviolet light with the capacity to generate both long- and shortwave spectra is a highly efficient aid in the identification of monazite and zircon.

The quantitative analysis employed both the point count method for very small samples and the Terry and Chillingar Diagrams method (Terry and Chillingar, 1955). The visual percents of the minerals were determined for each of the six fractions and entered in a Quattro Pro spreadsheet where they were combined. The weight percents are reported in Table 1.

\section{RESULTS}

Heavy mineral results are shown in Table 1 for each interval sampled. Garnet and pyroboles are depleted in the pyrite-rich intervals (Figs. 2, 3). These same intervals are generally enriched in zircon, tourmaline, and rutile (ZTR), which are chemically and mechanically resistant phases (Fig. 4). Higher proportions of ZTR and leucoxene reflect increased alteration of the heavy-mineral suite. Ilmenite content ranges between $30 \%$ and $40 \%$ of the sum of the magnetic fractions (Table 1; Fig. 4). Economically important heavy minerals (EHM) are ilmenite, leucoxene, the aluminosilicates, zircon, rutile, and monazite. The sample from $38.1 \mathrm{ft}(11.6 \mathrm{~m})$ has the highest percentage of EHM (1.588 wt\% of the bulk, normalized to exclude quartz and pyrite). All of the others are under $1 \%$ of the bulk sample weight. The average weight percent of the bulk for the EHM is under $0.5 \%$ (Table 1; Figs 2, 4). The low EHM content of these samples (av- 
Figure 1. Weight percent gravel/shells, sand, and silt/clay as a function of depth. Data come from 1-in half-core samples collected at depth intervals as labeled. The intervals from 155.8 to $258.0 \mathrm{ft}$ contain no gravel/shells.

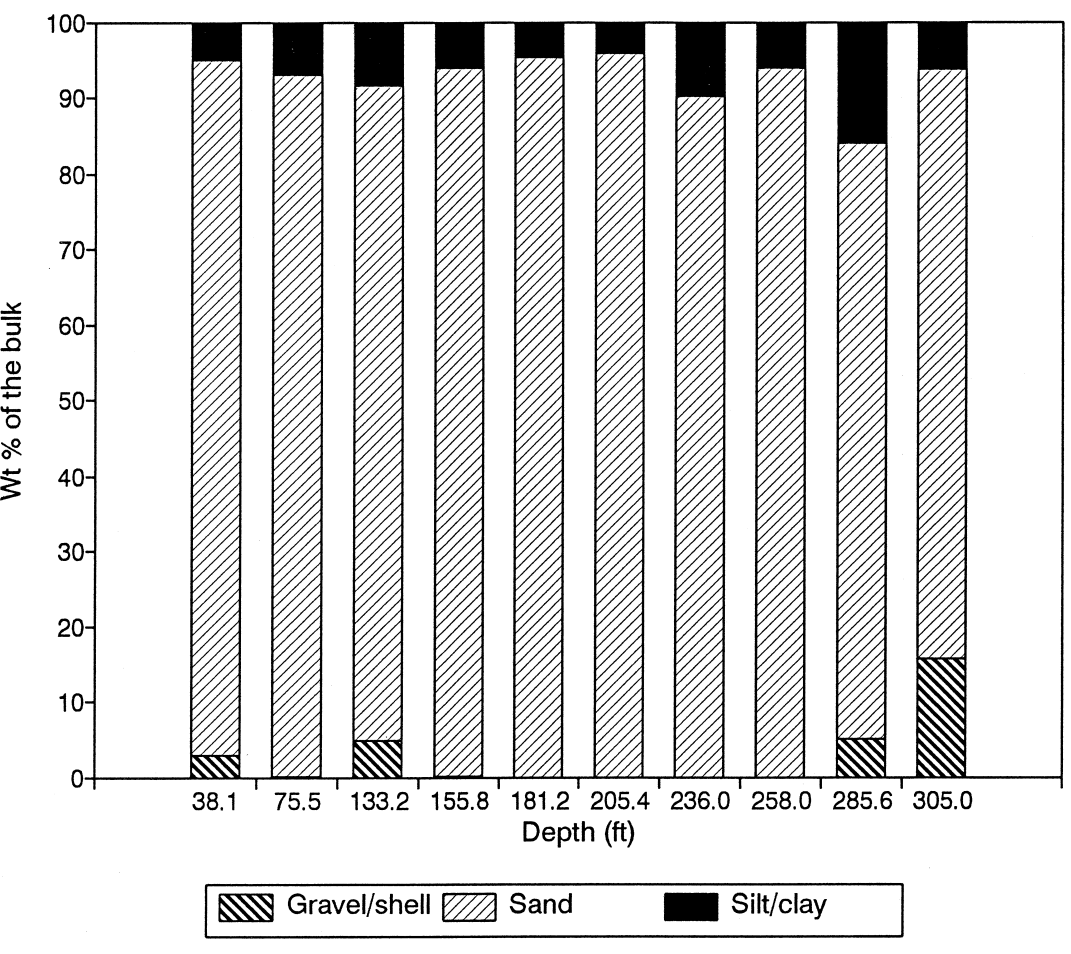

Continental Shelf. Virginia Division of Mineral Resources Publication, 103.

Mange, M.A., and Maurer, H.F.W., 1992. Heavy minerals in colour: New York (Chapman and Hall).

Miller, K.G., et al., 1996. Proc. ODP, Init. Repts.,150X (Suppl.): College Station, TX (Ocean Drilling Program).

Owens, J.P., Sugarman, P.J., Sohl, N.F., and Orndorff, R.C., 1995. Geologic map of New Jersey: Southern Sheet. Open-File Rep.-U.S. Geol. Surv., 95-254.

Terry, R.D., and Chillingar, G.V., 1955. Summary of "Concerning some additional aids in studying formations" by M.S. Shvetsov. J. Sediment. Petrol., 25:229-234.

Uptegrove, J., Grosz, A.E., Maharaj, S.V., Muller, F.L., Muessig, K., Farnsworth, J., Burbanck, G.P., and Cheung, T., 1991. Preliminary textural and mineralogical analyses of vibracore samples collected between Absecon and Barnegat Inlets, New Jersey. Open-File Rep.-N.J. Geol. Surv., 91-3.

Date of initial receipt: 8 April 1996

Date of acceptance: 24 July 1996

Ms 150XSR-334 
Table 1. Textural and mineralogical data on samples from the Leg 150X core, Cape May, NJ.

\begin{tabular}{|c|c|c|c|c|c|c|c|c|c|c|c|c|c|c|}
\hline Sample & $\begin{array}{l}\text { Bulk } \\
\text { weight } \\
\text { (g) }\end{array}$ & $\begin{array}{l}>2 \mathrm{~mm} \\
\text { gravel, } \\
\text { shells } \\
(\mathrm{wt} \%)\end{array}$ & $\begin{array}{c}>0.063 \\
\mathrm{~mm} \text { to } \\
<2 \mathrm{~mm} \\
\text { sand } \\
(\mathrm{wt} \%)\end{array}$ & $\begin{array}{c}<0.063 \\
\mathrm{~mm} \\
\text { silt, } \\
\text { clay } \\
(\mathrm{wt} \%)\end{array}$ & $\begin{array}{c}\text { Heavy } \\
\text { liquid } \\
\text { sink } \\
(\mathrm{g})\end{array}$ & $\begin{array}{c}\text { Weight } \\
203 \\
\text { (g) }\end{array}$ & $\begin{array}{c}\text { Weight } \\
204 \\
\text { (g) }\end{array}$ & $\begin{array}{c}\text { Weight } \\
205 \\
\text { (g) }\end{array}$ & $\begin{array}{c}\text { Weight } \\
206 \\
(\mathrm{~g})\end{array}$ & $\begin{array}{c}\text { Weight } \\
207 \\
\text { (g) }\end{array}$ & $\begin{array}{c}\text { Weight } \\
208 \\
(\mathrm{~g})\end{array}$ & $\begin{array}{c}\text { Sum of } \\
\text { magnetic } \\
\text { fraction } \\
\text { weights }\end{array}$ & $\begin{array}{c}\text { Ilmenite } \\
\text { (wt } \%)\end{array}$ & $\begin{array}{l}\text { Garnet } \\
\text { (wt } \%)\end{array}$ \\
\hline 38.1 & 69.46 & 2.88 & 92.14 & 4.98 & 2.172 & 0.058 & 0.313 & 0.431 & 0.134 & 0.058 & 1.135 & 2.129 & 44.92 & 5.11 \\
\hline 75.5 & 70.59 & 0.13 & 93.07 & 6.80 & 0.798 & 0.026 & 0.123 & 0.417 & 0.073 & 0.042 & 0.101 & 0.782 & 35.02 & 8.90 \\
\hline 133.2 & 89.87 & 4.78 & 86.79 & 8.42 & 2.012 & 0.098 & 0.372 & 0.401 & 0.123 & 0.111 & 0.904 & 2.008 & 31.35 & 3.43 \\
\hline 155.8 & 98.37 & 0.05 & 93.93 & 6.02 & 0.656 & 0.005 & 0.016 & 0.077 & 0.082 & 0.151 & 0.306 & 0.636 & 27.85 & 0.74 \\
\hline 181.2 & 101.40 & 0.00 & 95.27 & 4.73 & 0.302 & 0.001 & 0.006 & 0.011 & 0.011 & 0.031 & 0.210 & 0.270 & 27.85 & 1.16 \\
\hline 205.4 & 68.32 & 0.00 & 95.87 & 4.13 & 0.076 & 0.001 & 0.004 & 0.003 & 0.001 & 0.006 & 0.059 & 0.073 & 39.47 & 0.86 \\
\hline 236.0 & 61.52 & 0.00 & 90.22 & 9.78 & 0.615 & 0.013 & 0.130 & 0.052 & 0.176 & 0.044 & 0.201 & 0.616 & 42.07 & 4.14 \\
\hline 258.0 & 60.38 & 0.00 & 93.90 & 6.10 & 0.317 & 0.001 & 0.005 & 0.018 & 0.012 & 0.017 & 0.310 & 0.362 & 23.77 & 0.44 \\
\hline 285.6 & 81.93 & 5.13 & 78.97 & 15.90 & 0.222 & 0.012 & 0.033 & 0.059 & 0.025 & 0.019 & 0.065 & 0.213 & 43.27 & 9.83 \\
\hline 305.0 & 71.16 & 15.60 & 78.14 & 6.26 & 0.305 & 0.011 & 0.043 & 0.052 & 0.028 & 0.017 & 0.150 & 0.302 & 44.42 & 4.22 \\
\hline Minimum: & & & & & & & & & & & & & 23.77 & 0.44 \\
\hline Mean: & & & & & & & & & & & & & 36.00 & 3.88 \\
\hline Maximum: & & & & & & & & & & & & & 44.92 & 9.83 \\
\hline St. Dev. (Sample): & & & & & & & & & & & & 7.87 & 3.35 & 9.73 \\
\hline
\end{tabular}

\begin{tabular}{|c|c|c|c|c|c|c|c|c|c|c|c|c|c|c|}
\hline Sample & $\begin{array}{c}\text { Pyroboles } \\
\text { (wt } \%)\end{array}$ & $\begin{array}{c}\text { Epidote } \\
\text { (wt } \% \text { ) }\end{array}$ & $\begin{array}{c}\text { Staurolite } \\
\text { (wt } \%)\end{array}$ & $\begin{array}{l}\text { Leucoxene } \\
(\mathrm{wt} \%)\end{array}$ & $\begin{array}{c}\text { Tourmaline } \\
\text { (wt } \%)\end{array}$ & $\begin{array}{c}\text { Monazite } \\
\text { (wt } \%)\end{array}$ & $\begin{array}{c}\text { Alumino- } \\
\text { silicates } \\
\text { (wt } \%)\end{array}$ & $\begin{array}{l}\text { Zircon } \\
\text { (wt\%) }\end{array}$ & $\begin{array}{l}\text { Rutile } \\
\text { (wt } \% \text { ) }\end{array}$ & $\begin{array}{l}\text { Other } \\
\text { (wt\%) }\end{array}$ & $\begin{array}{c}\text { Sum } \\
(\mathrm{wt} \%)\end{array}$ & $\begin{array}{l}\text { EHM } \\
(w t \%)\end{array}$ & $\begin{array}{c}\text { EHM as } \\
\text { wt } \% \text { of } \\
\text { bulk }\end{array}$ & $\begin{array}{c}\text { ZTR } \\
\text { (wt } \%)\end{array}$ \\
\hline 38.1 & 6.88 & 1.36 & 3.07 & 9.48 & 3.64 & 0.39 & 13.47 & 7.88 & 0.04 & 3.72 & 99.96 & 76.17 & 1.588 & 11.56 \\
\hline 75.5 & 32.02 & 3.36 & 1.07 & 3.38 & 1.31 & 0.10 & 9.48 & 1.47 & 0.41 & 3.47 & 100.00 & 49.86 & 0.522 & 3.19 \\
\hline 133.2 & 8.10 & 3.97 & 6.37 & 5.44 & 6.59 & 0.52 & 14.06 & 8.98 & 2.67 & 8.43 & 99.90 & 63.01 & 0.713 & 18.24 \\
\hline 155.8 & 0.00 & 0.00 & 24.95 & 5.82 & 7.32 & 0.00 & 14.60 & 15.08 & 1.95 & 1.70 & 100.00 & 65.30 & 0.209 & 24.35 \\
\hline 181.2 & 0.14 & 0.00 & 1.00 & 21.38 & 3.84 & 0.00 & 29.90 & 8.19 & 0.00 & 6.54 & 100.00 & 87.32 & 0.067 & 12.03 \\
\hline 205.4 & 0.54 & 0.00 & 0.63 & 15.50 & 0.50 & 0.00 & 17.89 & 9.76 & 3.25 & 11.59 & 100.00 & 85.88 & 0.023 & 13.52 \\
\hline 236.0 & 0.32 & 3.20 & 1.68 & 23.54 & 3.36 & 0.00 & 11.89 & 3.66 & 0.37 & 5.76 & 100.00 & 81.53 & 0.727 & 7.39 \\
\hline 258.0 & 0.43 & 0.94 & 0.19 & 32.17 & 0.92 & 0.00 & 23.60 & 0.00 & 0.00 & 17.54 & 100.00 & 79.53 & 0.124 & 0.92 \\
\hline 285.6 & 7.44 & 0.15 & 2.72 & 12.12 & 4.89 & 0.00 & 8.80 & 5.68 & 0.74 & 4.35 & 100.00 & 70.62 & 0.150 & 11.32 \\
\hline 305.0 & 8.49 & 2.00 & 0.83 & 12.31 & 2.55 & 0.00 & 7.71 & 10.83 & 2.15 & 4.48 & 100.00 & 77.43 & 0.228 & 15.54 \\
\hline Minimum: & 0.00 & 0.00 & 0.19 & 3.38 & 0.50 & 0.00 & 7.71 & 0.00 & 0.00 & 1.70 & & 49.86 & 0.023 & 0.92 \\
\hline Mean: & 6.44 & 1.50 & 4.25 & 14.11 & 3.49 & 0.10 & 15.14 & 7.15 & 1.16 & 6.76 & & 73.66 & 0.435 & 11.81 \\
\hline Maximum: & 32.02 & 3.97 & 24.95 & 32.17 & 7.32 & 0.52 & 29.90 & 15.08 & 3.25 & 17.54 & & 87.32 & 1.588 & 24.35 \\
\hline St. Dev. (Sample): & 1.55 & 7.49 & 9.17 & 2.30 & 0.19 & 6.99 & 4.54 & 1.23 & 4.71 & & 11.60 & 0.480 & 6.90 & \\
\hline
\end{tabular}

Notes: All sample intervals $=0.1 \mathrm{ft}$ (e.g., sample 38.1 is from the interval 38.1 to $38.2 \mathrm{ft} \mathrm{depth}$ ). Textural data are separated into wt $\%$ gravel/shell material, sand, and silt/clay based on a modified Udden-Wentworth scale (with designation of material $>2 \mathrm{~mm}$ as gravel). "Heavy liquid sink" is the weight of the residual material after separation with sodium polytungstate (S.G. $\geq 2.89)$. The weights of the magnetic separates (203 through 208) show the relative abundance of the magnetic separates, as discussed in the text. Weight percents of the sum of the magnetic fractions are listed for eleven minerals in the heavy-mineral suite. The name "Pyroboles" is the sum of pyroxene and amphibole. "Aluminosilicates" is the sum of sillimanite, kyanite, and andalusite. "Other" can include chlorite, muscovite, biotite and ironstone, and rock fragments, or rarely glauconite clayballs, hematite, apatite, and spinel. The "economic heavy minerals" (EHM) is the sum of ilmenite, leucoxene, zircon, monazite, the aluminosilicates, and rutile. ZTR is the sum of zircon, tourmaline, and rutile which are considered to be highly resistant to weathering. Thus, high wt\% ZTR indicates a highly weathered sample. The data were normalized excluding quartz and pyrite, which were entrained in the heavy-mineral sink. St. Dev. = standard deviation. 


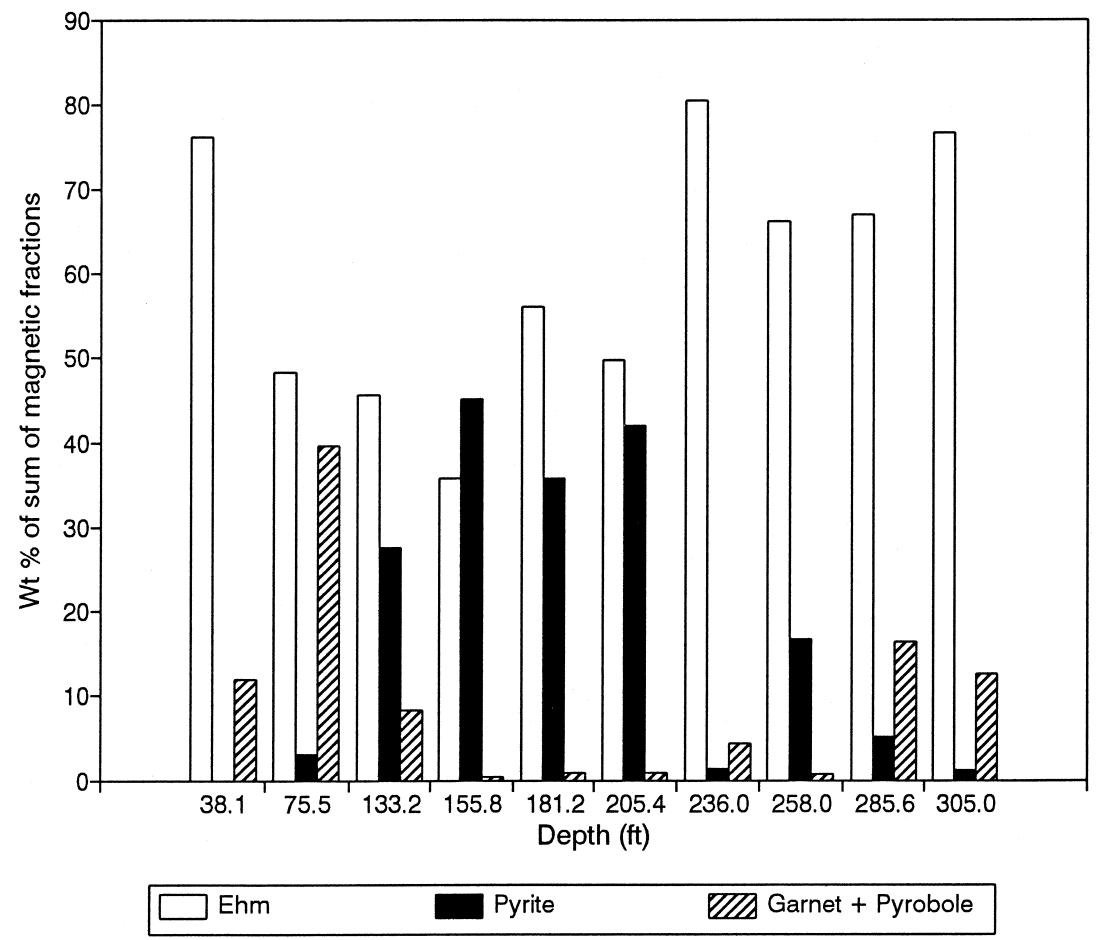

Figure 2. Weight percent economically important heavy minerals (EHM, defined as the sum of ilmenite, leucoxene, aluminosilicates, zircon, rutile, and monazite), pyrite, and combined garnet and pyroboles as a function of depth. The pyrite-rich zone (intervals from 133.2 to $205.4 \mathrm{ft}$ ) is de pleted in garnet and pyroboles. The EHM is also lower in the pyrite-rich zone. These values are normalized to exclude quartz.

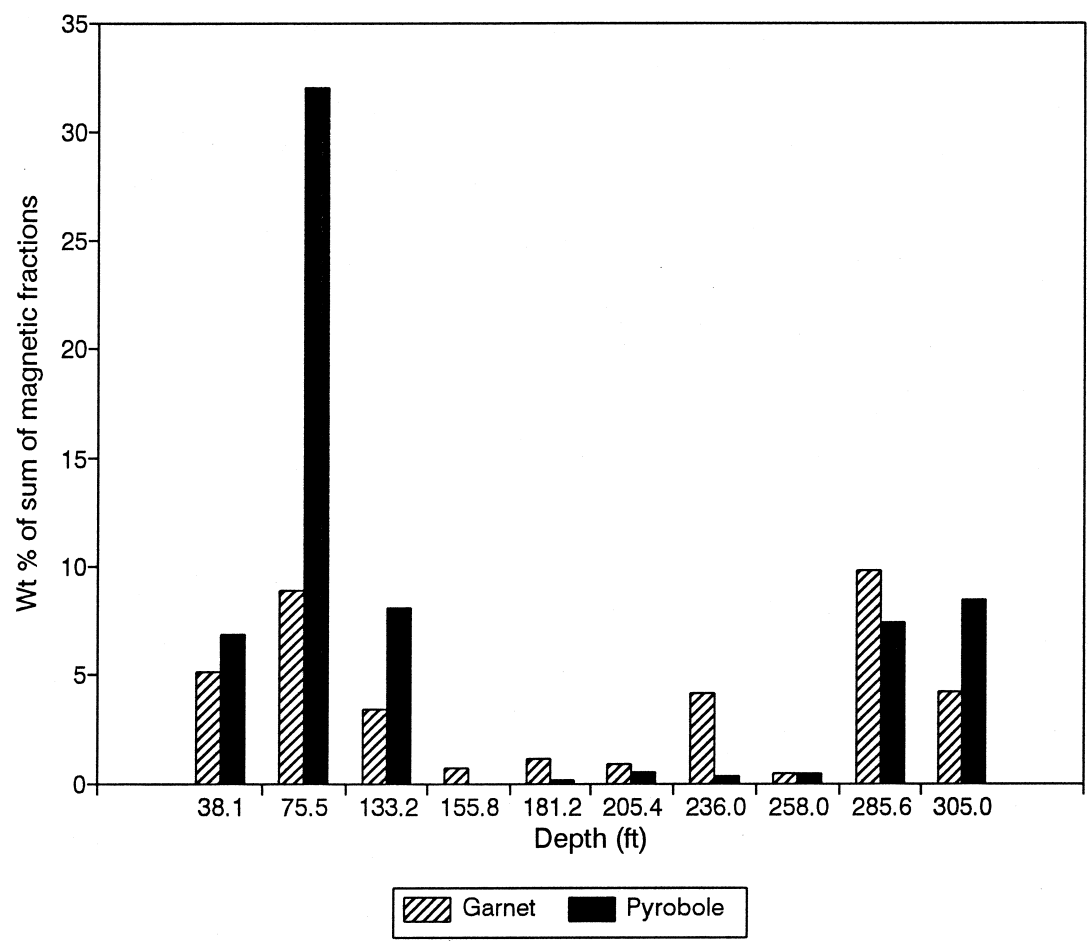

Figure 3. Weight percent garnet and pyroboles show a decrease in the intervals from 155.8 to $258.0 \mathrm{ft}$. This corresponds to a zone of pyrite-rich samples (see Fig. 2). These values are normalized to exclude quartz and pyrite. 


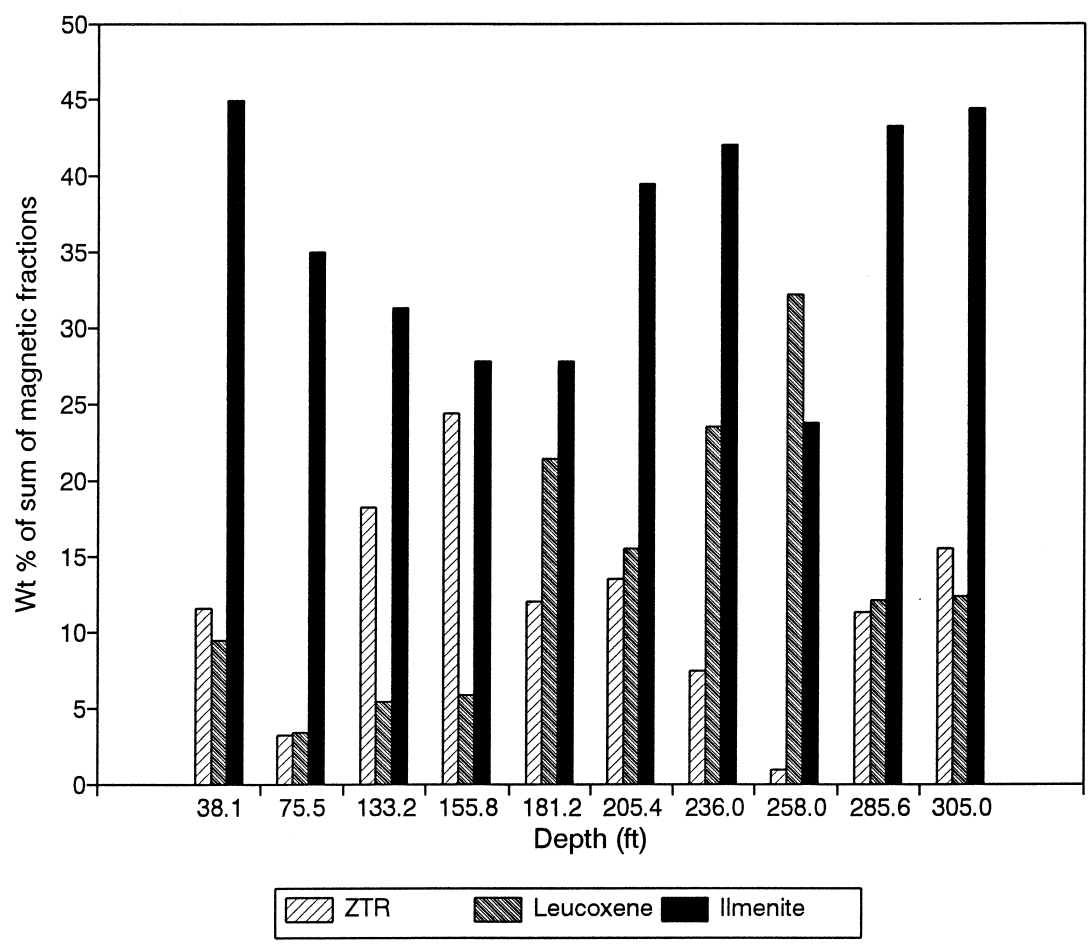

Figure 4. Weight percent ZTR index (zircon + tourmaline + rutile), leucoxene, and ilmenite. Relatively high ZTR is indicative of a highly weathered mineral suite (e.g., intervals 133.2 and $155.8 \mathrm{ft}$ ). Samples with a relatively high ratio of leucoxene to ilmenite also indicate extensive weathering (intervals 181.2 and $258.0 \mathrm{ft}$ ). These values are normalized to exclude quartz and pyrite. 